\title{
Development and Biochemical Composition
} Assessment of Fish Powders from Bangladeshi Indigenous Fish Species and Shelf-Life Characteristics Evaluation During 90 Days of Room Temperature $\left(27^{\circ} \mathrm{C}-30^{\circ} \mathrm{C}\right)$ Storage

\author{
Niaz Mahmud1", Shovon Al-Fuad1, Shahriar Islam Satya1, Abdullah Al Mamun1, Suzon Ahmed1, \\ Adnan Karim², Monirul Islam,4, Jannatul Ferdaus', Shofiqul Islam², Nazmus Sakib2, \\ Jui Yeasmin ${ }^{5}$ \\ ${ }^{1}$ Department of Nutrition and Food Technology, Jashore University of Science and Technology, Jashore, Bangladesh \\ ${ }^{2}$ Department of Genetic Engineering and Biotechnology, Jashore University of Science and Technology, Jashore, Bangladesh \\ ${ }^{3}$ State Key Laboratory of Food Science and Technology, Jiangnan University, Wuxi, China \\ ${ }^{4}$ Rural Development Academy (RDA), Bogra, Bangladesh \\ ${ }^{5}$ Department of Genetic Engineering and Biotechnology, University of Rajshahi, Rajshahi, Bangladesh \\ Email: *niaz_nft@just.edu.bd
}

How to cite this paper: Mahmud, N., Al-Fuad, S., Satya, S.I., Al Mamun, A., Ahmed, S., Karim, A., Islam, M., Ferdaus, J., Islam, S., Sakib, N. and Yeasmin J. (2019) Development and Biochemical Composition Assessment of Fish Powders from Bangladeshi Indigenous Fish Species and Shelf-Life Characteristics Evaluation During 90 Days of Room Temperature $\left(27^{\circ} \mathrm{C}-30^{\circ} \mathrm{C}\right)$ Storage. Food and Nutrition Sciences, 10, 963-984.

https://doi.org/10.4236/fns.2019.108069

Received: July 11, 2019

Accepted: August 13, 2019

Published: August 16, 2019

Copyright $\odot 2019$ by author(s) and Scientific Research Publishing Inc. This work is licensed under the Creative Commons Attribution International License (CC BY 4.0).

http://creativecommons.org/licenses/by/4.0/

\section{Abstract}

In Bangladesh, Fish is a major source of daily protein intake of millions of people but most of the fishes are consumed here as fresh fish which is highly susceptible to damage during transportation and marketing. Therefore, an innovative approach was undertaken to process the fish to avoid damage and extend shelf-life while preserving the nutritional qualities to facilitate the more efficient use of fish as a source of protein and other essential nutrients. This study was conducted to develop some dried protein-enriched fish powders from some commonly consumed fish species in Bangladesh and the nutritional, sensorial, and safety qualities were assessed. Five indigenous abundant fish species including small indigenous fish (SIS) and carp fishes namely Awaous grammepomus, Channa punctata, Puntius puntio, Hypophthalmichthys molitrix and Labeo rohita were used for the preparation of dried protein-enriched fish powders. Biochemical, trace elements, sensorial, total viable count (TVC), $\mathrm{pH}$, peroxide value, and moisture reconstitution during 90 days storage period were performed by standard analytical methods. The moisture, protein, fat, ash, carbohydrate (including fiber), and energy contents were ranged from $(6.84 \%$ to $8.85 \%)$, (70.80\% to $75.80 \%)$, (5.85\% to $8.04 \%)$, (7.66\% to $9.19 \%)$, $(3.14 \%$ to $6.01 \%)$ and $(367.50 \%$ to $379.61 \% \mathrm{kcal}) / 100 \mathrm{~g}$ re- 
spectively. Highest content of protein was found in A. grammepomus (75.80\%) samples and the lowest in H. molitrix $(70.80 \%)$ samples. Maximum calcium content was found in sample L. rohita $(2.54 \mathrm{~g} / \mathrm{kg})$ and minimum in C. punctata as $(2.43 \mathrm{~g} / \mathrm{kg})$. Maximum iron content was found in $H$. molitrix $(0.15 \mathrm{~g} / \mathrm{kg})$ and minimum in A. grammepomus. As for the phosphorous content the $L$. rohita samples contained the highest $(1.4 \mathrm{~g} / \mathrm{kg})$ and the lowest in C. punctata $(0.73 \mathrm{~g} / \mathrm{kg})$ samples. The $\mathrm{pH}$, peroxide value $\left(\mathrm{mEq}\right.$ of $\mathrm{O}^{2} / \mathrm{kg}$ of fat), and moisture reconstitution $(\mathrm{g} / 100 \mathrm{~g})$ during 90 days were ranged from (5.30 to 8.17$)$, (8.60 to 16.77 ), and (6.84 to 13.83 ) respectively. Microbial loads over the 90 days period were in acceptable range at the end of 90 days storage period. On the basis of biochemical qualities, sensorial and microbial attributes our findings suggest that the dried fish powders are enriched with macro and micro-nutrients especially proteins and could safely be used at least up to 3 months for food applications.

\section{Keywords}

Biochemical Quality, Trace Element, Sensory Evaluation, Microbial Analysis

\section{Introduction}

Fish provides approximately $16 \%$ of all animal proteins and occupies a considerable contribution in ameliorating the fatty acids, amino acids, lipid-soluble vitamins and micronutrients requirement of daily life throughout the world [1] [2]. In Bangladesh, fish is an inimitable animal-source food in the diet of millions accounting for approximately $60 \%$ of animal protein intake at $18.1 \mathrm{~kg}$ consumed per person per year [3] [4]. Bangladesh, the country possesses miscellaneous and profuse aquatic resources with 267 freshwater fish species with an annual production of 3.1 million tons [3] [4]. However, despite the lucid importance of fish in Bangladeshi diet, the existing utilization of fish and the diversity of application of fish species are decreasing significantly. In this regard to facilitate the utilization of fish species, we developed some dried protein-enriched fish powders from Bangladeshi small indigenous fish (SIS) namely Awaous grammepomus, Channa punctata and Puntius puntio and two other species from carp family namely Hypophthalmichthys molitrix and Labeo rohita. These fresh water species have been found inundated with various macro and micronutrients, especially for their robust content of vitamins, minerals and protein contents [5].

The primary objective of this study was to develop some dried healthy protein-enriched fish powders for food application and to investigate its nutritional, sensorial and shelf-life aspects. Since fish is highly perishable to oxidative damage, the conservation method is important to strengthen the stability during storage and increase the shelf-life [6]. A very popular conservation method, drying has been found extremely helpful in reducing the burden of moisture which leads to the onset of microbial spoilage [6] [7]. In this study we used both sun 
drying and mechanical drying methods in a controlled environment to develop an innovative and subtle fish dry processing method, especially targeting to develop the perfect time-temperature set up while keeping the nutritional benefits at best. Moreover, the powder technology of food materials is flourishing and becoming popular [7]. Formulation and analysis of the physical and chemical characteristics of food powder materials are important because the understanding of the parameters is effective in developing new powder-based products while reducing associated costs, the extra burden of new formulation and promoting optimization in the processing phase and product storage [7] [8]. In addition, powder foodstuffs have significant effects on the final products because of its long stabilities [9] [10].

The application of fish powders is gaining popularity among researchers for their diverse range of scopes [2] [6]. A recent study investigated the effect of silver carp fish powders incorporation in soup powders and the results significantly improved the protein contents of the final soup powders [2]. Another study reported that instant Tilapia soup, made from Tilapia (Oreochromis niloticus) can be used in food industry on additive material for the development of new food items [6]. Since the dried protein-enriched fish powders are rich in nutrients and have an extended shelf-life, these could be supplied in global markets where demands for nutrient-rich dry foods are high. Furthermore, since the fish powders are the affluent source of nutrition, understanding of nutritional compositions of fish powder is fundamental in order to balance its value as food with other foods especially protein-enriched foods [11]. Alongside, it is also compulsory to have decent figures on the nutritional composition of fish powders in order to make the preeminent use of them as food resources and to build up the technology of processing fish powder and other fisheries foodstuffs [12]. Another important reason which could be attributed to the conversion of raw fish to powder form is the highly desirable functional properties of fish protein [13]. A study reported that protein powders from herring and arrow tooth were found good sources of high-quality fish protein with many desirable functional properties as an excellent source of high-quality protein; noticeably, the presence of some of the essential amino acids such as lysine and methionine [14].

Elaboration of potential ingredients in powder form by using fishes is increasing as an alternative since the trend to produce health-based products with more healthy and stable ingredients is expanding [15]. Fish powders as an ingredient can be incorporated into foods to increase the added-value of products, avoid the burden of economic loss to the fish industry, diminish environmental impacts, and contribute consumers with a nutritious, low-cost, long shelf-life and easy preparation of foods [16] [17]. Regardless of the availability of the enormous amount of fish protein consumption in Bangladesh, there are a few reports on the nutritive or caloric values of dried fishes which make people confused regarding selecting the required amount of calorie from fishes and fish products. Therefore, the present study is intended to estimate the amount of to- 
tal protein, fat, moisture, ash, carbohydrate (including fiber), phosphorus, iron, and calcium content of fish powders of some fishes in order to make the consumers more attentive on the nutritional content of fish powder as well as to strengthen the preferences among consumers in choosing fish powder fortified products based on its nutrient values. The drying of fishes as a conversion method (fresh raw fish to dried form) in order to make powders is cheap, feasible and effective [18].

While mechanical drying is safe and quite expensive, as a traditional method of preservation and processing, simple and inexpensive rack sun drying is one of the most widely applicable fish preservation techniques that dry fishes through heat from sun and the air current carries water away while facilitating the circulation of air from both top and bottom and inhibiting contamination of the product with sand or dust leading to quality assurance [19]. Some other popular fish processing methods include smoking, drying and curing of fish [18].

For centuries all of these processing methods are developed by means of prolonging shelf-life and improving its sensorial qualities such as flavors and texture attributes [20] [21]. Considering the vast amount of incidents of fish spoilage across the world it is an utmost urgency to develop efficient fish conversion processing methods in such a manner that would not let the fishes become deteriorated and spoiled soon after slaughtering [22] [23]. Preservation and processing therefore become a vital part of industrial and small-scale household fisheries to retain their freshness qualities for a long time while targeting minimum loss of flavor, taste, odor, nutritive values and microbial losses.

\section{Materials and Methods}

\subsection{Sample Collection and Processing of Fish Powders}

Five fresh locally available fish species (Awaous grammepomus, Channa punctata, Puntius puntio, Hypophthalmichthys molitrix and Labeo rohita) were used for the preparation of dried protein-enriched fish powders. Samples were purchased from super market of Jessore Sadar, Bangladesh (Figure 1) and immediately transferred to the laboratory of nutrition and food technology department, Jashore University of Science and Technology where the major parts of this study were carried out. Samples were stored at $18^{\circ} \mathrm{C}$ before initiating the experiment. Average size and weight of the raw fish samples were then calculated and expressed as (Mean \pm SD) and a list of collected fish species along with their scientific name, family, English name, local name, average size and average weight are presented in (Table 1).

Fish samples were then processed and muscles and bones were separated. Disinfectant treatments by using ascorbic acid $(1.5 \% \mathrm{v} / \mathrm{v})$ solutions were then applied to the fish muscles and dried in mechanical dryer followed by sun drying (3 hours). The muscle samples were arranged in separate perforated trays and dried in a mechanical dryer at $\left(75^{\circ} \mathrm{C}-80^{\circ} \mathrm{C}\right)$ for about $22 \pm 2$ hour, grinded. For bone, the bone samples were dried in a mechanical dryer at $\left(55^{\circ} \mathrm{C}-60^{\circ} \mathrm{C}\right)$ for 


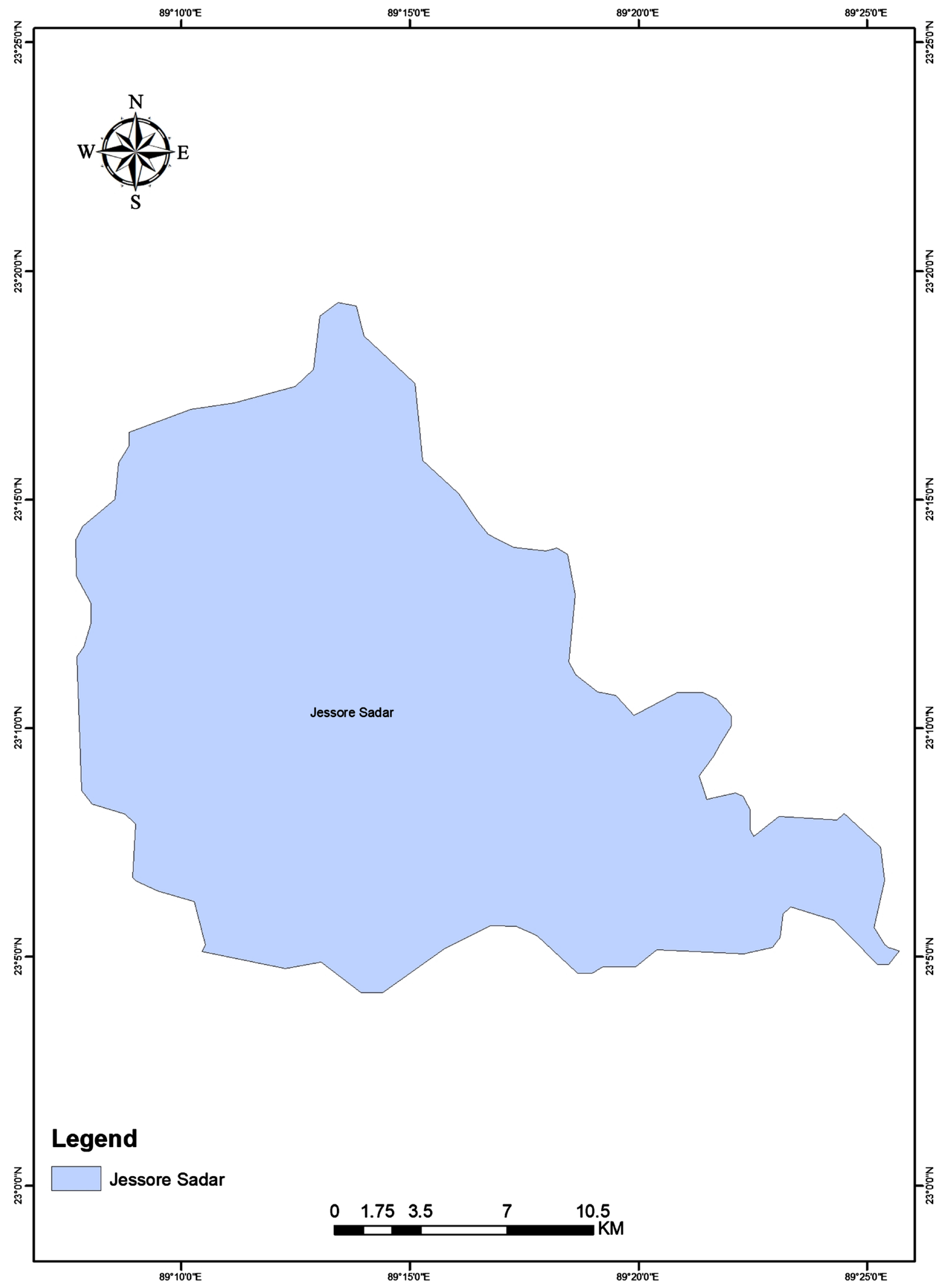

Figure 1. Map of study area (Jessore Sadar, Bangladesh). 
Table 1. List of collected fish species along with their scientific name, family, English name, local name, average size and average weight.

\begin{tabular}{|c|c|c|c|c|c|}
\hline \multirow{2}{*}{ Fish samples } & \multicolumn{5}{|c|}{ Physical parameters } \\
\hline & Family & English name & Local name & $\begin{array}{l}\text { Average size }(\mathrm{cm}) \\
\quad(\text { Mean } \pm \mathrm{SD})\end{array}$ & $\begin{array}{l}\text { Average weight }(\mathrm{cm}) \\
\quad(\text { Mean } \pm \text { SD })\end{array}$ \\
\hline Awaous grammepomus ( $A G)$ & Oxudercidae & Scribbled Goby & Bele & $8.83 \pm 0.84$ & $22.30 \pm 1.92$ \\
\hline Channa punctata $(C P)$ & Channidae & Spotted Snakehead & Taki & $12.83 \pm 0.97$ & $27.50 \pm 1.80$ \\
\hline Puntius puntio $(P P)$ & Cyprinidae & Puntio Barb & Punti & $4.67 \pm 0.42$ & $6 \pm 1.41$ \\
\hline Hypophthalmichthys molitrix (HM) & Cyprinidae & Silver Carp & Silver & $26.95 \pm 1.20$ & $885.40 \pm 5.08$ \\
\hline Labeo rohita $(L R)$ & Cyprinidae & Rohu & Rui & $28.08 \pm 1.35$ & $913 \pm 8.37$ \\
\hline
\end{tabular}

Average size and weight data are not significantly different at $\mathrm{p}<0.05$.

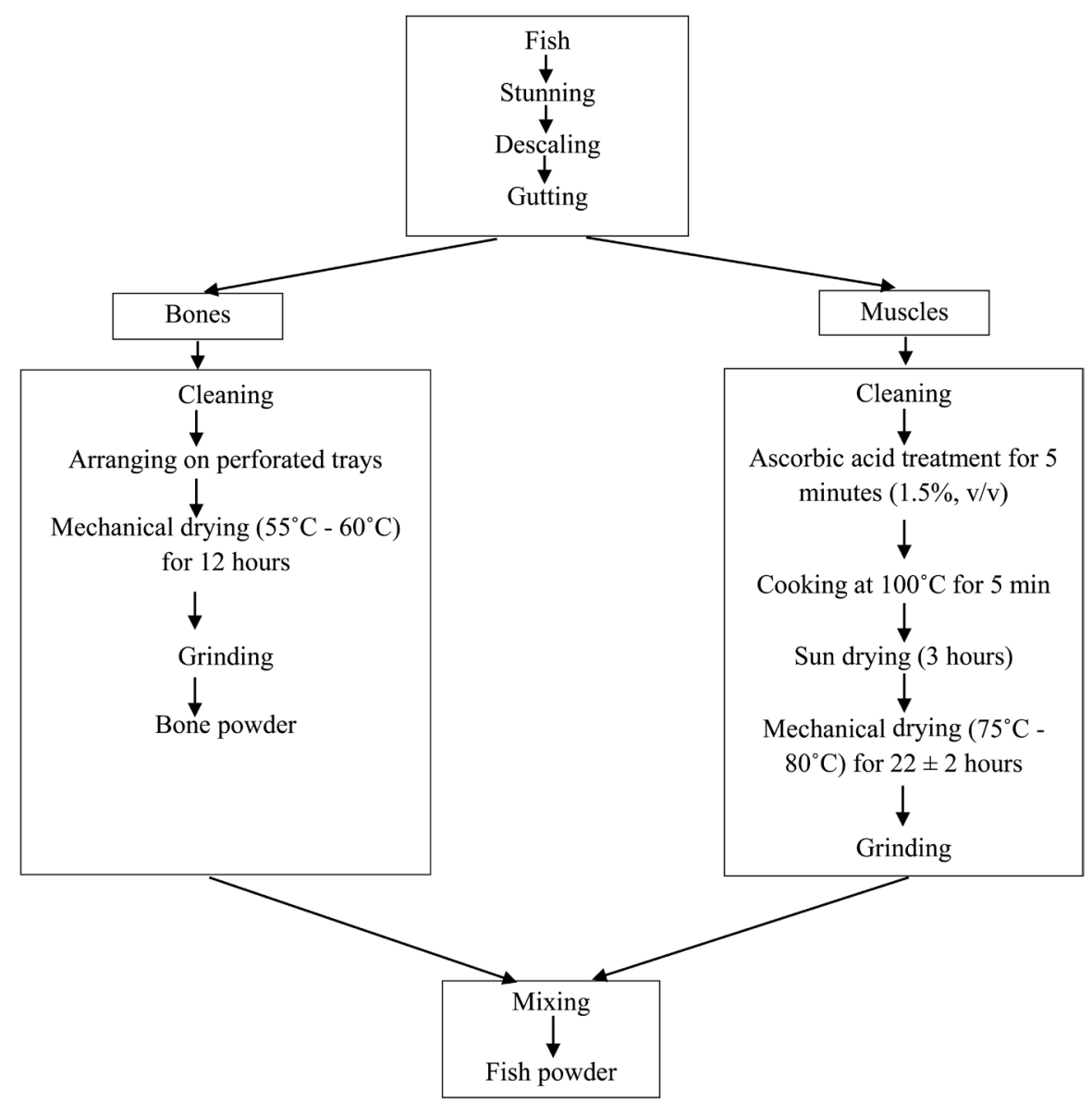

Figure 2. Layout of the processing of dried fish powders.

about 12 hours, grinded. The grinded muscle and bone samples were then mixed separately and packaged into polypropylene bags and stored at room temperature at $\left(27^{\circ} \mathrm{C}-30^{\circ} \mathrm{C}\right) \pm 2^{\circ} \mathrm{C}$ for biochemical, sensorial and microbial analysis. A complete processing layout of fish powders is presented in (Figure 2). 


\subsection{Biochemical Analysis of Fish Powder}

Biochemical composition for the moisture, protein, ash, fat and carbohydrate (including fiber) of the dried fish powders were estimated according to different standard analytical methods developed for proximate analysis (AOAC, 2003) [24] [25]. The carbohydrate contents were determined by calculated difference method and the energy value was determined by multiplying the proportion of protein, fat, and carbohydrate by their respective physiological energy values and taking the sum of the products [26]. Determination of moisture of dried fish powders were conducted following the (AOAC, 2003) method [24]. Dried fish powder samples were dried at elevated temperature and reported the loss in weight in terms of moisture by the following equation.

$$
\text { Moisture content }(\%)=\frac{\text { Loss of weight }}{\text { Weight of sample taken }} \times 100
$$

The crude protein of the dried fish powders were determined by Micro-Kjeldhal method [20] [24]. Briefly, the percentage of nitrogen of fish samples was calculated and the percentage of protein in the samples was calculated by multiplying the percentage of $\mathrm{N}$ with an empirical factor 6.25.

$$
\begin{aligned}
\mathrm{N}(\%)= & (\text { Titration reading }- \text { blank reading }) \times \text { Strength of acid } \\
\times & \frac{100}{\mathrm{~S}} \times \frac{100}{\text { Weight of sample }} \\
& \text { Protein content }(\%)=\text { Total } \mathrm{N}(\%) \times 6.25
\end{aligned}
$$

Total lipid content of dried fish powders were determined by method as described in Bligh and Dyer method [27] and calculated using following equation.

$$
\text { Total lipid content }(\%)=\frac{\text { Weight of residue }}{\text { Weight of sample taken }} \times 100
$$

The ash content of the fish samples was determined as the inorganic residues such as oxides, sulphates, silicates and chlorides left behind, in the dry muscle. The samples heated to the temperatures of $500^{\circ} \mathrm{C}-600^{\circ} \mathrm{C}$ in a muffle furnace for about 3 hours. Afterwards, the percentage of ash content was calculated according to [24] [26].

$$
\text { Ash content }(\%)=\frac{\text { Weight of ash }}{\text { Weight of sample taken }} \times 100
$$

\subsection{Trace Elements Analysis}

To determine the trace elements the calcium, iron, phosphorous, lead, cadmium and arsenic concentrations were studied. Mineral contents of the dried fish powders such as calcium, iron and phosphorus were estimated according to the standard methods. Calcium contents were determined according to the guidelines as described in flame method [28]. Iron concentration was measured by using APHA through Atomic Absorption Spectrophotometer (ELICO, SL 194). 
Phosphorus was determined by the Vanadomolybdate yellow color method as described in [29]. The dried fish powder samples were then subjected to analysis for the detection of heavy metals with slight modification as described in [30]. A known quantity of sample was weighed by an electronic balance and $5 \mathrm{ml}$ of diacid mixture ( $5 \mathrm{ml}$ conc. $\mathrm{HNO}_{3} ; 3 \mathrm{ml} 60 \% \mathrm{HClO}_{4}$ ) was added to each sample; then the content was mixed for overnight. Samples were then digested initially at $80^{\circ} \mathrm{C}$ temperature and later at $150^{\circ} \mathrm{C}$ for $2 \mathrm{~h}$. The completion of digestion was indicated by almost colorless condition of the material. The brown fumes also cease to exist at completion of digestion. The samples were separately filtered by using an ash less filter paper and volume made up to $25 \mathrm{ml}$ with $0.5 \% \mathrm{HNO}_{3}$ prepared for the determination of $\mathrm{As}, \mathrm{Cd}$ and $\mathrm{Pb}$ [31]. The samples were subjected to analysis by Atomic Absorption Spectrophotometer (HG-AAS, PG-990, PG Instruments, UK).

\subsection{Microbial Analysis}

The Total Viable Count (TVC) was carried out by the spread plate technique method [32]. The sample $(0.1 \mathrm{ml})$ of each dilution was taken onto each sterile Petridis and evenly spread on the solid nutrient medium and incubated at $37^{\circ} \mathrm{C}$ for 24 hours. The plates were screened for the presence of discrete colonies after incubation period and the actual numbers of bacteria were estimated as colony forming unit (CFU)/g as described in [32].

\subsection{Moisture Reconstitution Analysis}

Moisture contents were kept under investigation during the whole 90 days storage period following the (AOAC, 2003) method [24]. Moisture uptake of the dried fish samples were then recorded in an interval of 30 days during the 90 days storage period and the reconstitutions were estimated.

\section{6. $\mathrm{pH}$ and Peroxide Value (PV) Analysis}

To determine the $\mathrm{pH}$ contents of the dried fish powder samples, $1 \mathrm{~g}$ sample of each was homogenized in $10 \mathrm{ml}$ of distilled water and the mixture was filtered. The $\mathrm{pH}$ of the filtrate was measured using a $\mathrm{pH}$ meter [33]. And the Peroxide value (PV) was determined by titration method as described by Onwuka [34].

\subsection{Sensory Evaluation}

The developed dried protein-enriched fish powders were tested for sensorial acceptability using a hedonic test according to [35] [36] [37]. Trained panelists (n = 5) were selected from the Department of Nutrition and Food Technology of Jashore University of Science and Technology for the sensory evaluation on the basis of appearance, odor, texture and overall acceptability. A nine-point verbal category hedonic scale was used: 1 , dislike extremely; 5 , neither like nor dislike; 9, like extremely. The scale was presented as a line numbered $1-9$ with the beginning, middle, and end parameters specified. 


\subsection{Statistical Analysis}

Data analyses were carried out usinggraphpad prism (version 8.1.0) and Statistical Package for the Social Sciences (SPSS version 16.0 SPSS Inc. Chicago, Illinois, and U.S.A). Values were expressed as percentage and Mean \pm SD. The significance/non significance of results were determined using one-way ANOVA and Tukey's HSD Post Hoc Test. Values (Mean \pm SD) with different superscripts are significantly different at $\mathrm{p}<0.05$.

\section{Result and Discussion}

Since dried fishes are very popular food components in many parts of the world, especially for the feasibility of easy drying methods, it is important to investigate their utilization perspective regarding the biochemical, microbiological, and sensory properties. In the present work, five Bangladeshi locally available fish species were examined to develop some dried healthy fish powders while developing an easy and feasible drying procedure to facilitate nutrients consumption from fish sources. Newly developed fish powders were investigated for the biochemical, microbial, $\mathrm{pH}$, peroxide value and sensorial acceptance during a total of 90 days storage period to articulate the acceptance and utilization prospects of these dried fish powders as food components. In this regard; moisture, protein, fat, ash, carbohydrate were assessed from biochemical assessment; $\mathrm{Fe}, \mathrm{Ca}, \mathrm{P}, \mathrm{Pb}$, $\mathrm{Cd}$, and As contents were assessed for trace elements analysis; total viable count (TVC) for microbial growth, $\mathrm{pH}$, and Peroxide Value of fat were assessed for the shelf-life analysis and sensorial scores were analyzed to determine the consumer acceptance of the developed dried fish powders.

\subsection{Moisture}

The moisture contents of the five developed dried fish powders ranged from $6.84 \%$ to $8.85 \%$ (Table 2). The lowest moisture content was found in the sample A. grammepomus (6.84\%) and the highest in L. rohita (8.85\%). The quantities were found $(6.84,6.90,7.23,7.49$, and 8.85$) / 100 \mathrm{~g}$ for $A$. grammepomus, $C$. punctata, $P$. puntio, $H$. molitrix and L. rohita respectively. Moisture content of all the dried fish powder samples was below the standard level for microbial growth. In general the sun-dried fishes contain an average of $10 \%$ to $20 \%$ moisture [38] [39]. Moisture content is a critical factor in maintaining food quality because increase in moisture accelerates the growth of microbes and ultimately demolish the quality attributes. According to [40], microorganisms cannot grow when moisture content is below $8 \%$. On the other hand, when moisture is greater than $18 \%$, some microorganisms may be re-burgeoned gradually. Another investigation by [41] reveals that in case of dried food materials, the moisture content for dried food materials less than $10 \%$ is regarded as more efficacious for keeping the quality attributes. Our investigation also found that the moisture content of $L$. rohita was below the study by [42] in which they found the moisture contents of L. rohita $9.07 \%$. Another study [39] determined that the mois- 
ture content of seven Bangladeshi dried fish samples ranged from 11.65\% $13.50 \%$, which is significantly greater than our investigation [11]. Moreover, our findings are below the research by [11] where they found the moisture content of dried H. molitrix (13.95\%) and L. rohita (11.55\%) which are greater than our investigation.

\subsection{Ash}

The ash content of the five developed dried fish powders ranged from $7.66 \%$ to 9.19\% (Table 2). The highest content of ash was found in the sample P. puntio (9.19\%) and the lowest in H. molitrix (7.66\%). The quantities were found (8.10, 8.43, 9.19, 7.66, and 8.21) g/100g for A. grammepomus, C. punctata, P. puntio, $H$. molitrix and L. rohita respectively. Ash contents are the most consistent indicator of the presence of minerals [11]. Our study resembles with study [43] where they found the ash content of dried burrito fish powder (14.0\%) which is mostly consistent with our study. The highest contents of the ash in the developed dried fish powders beckon that it is a robust source of minerals and for efficient food application, it will surely improve the micronutrient profiles of food commodities.

\subsection{Protein}

In this study, the protein contents of the developed dried fish powders ranged from $70.80 \%$ to $75.80 \%$ (Table 2). The highest value was found in A. grammepomus $(75.80 \%)$ and the lowest in $H$. molitrix $(70.80 \%)$. The quantities were found $(75.80,73.36,72.90,70.80$, and 72.63) g/100g for A. grammepomus, $C$. punctata, $P$. puntio, $H$. molitrix and L. rohita respectively. Our findings reveal that the protein contents in all the samples are higher which make them highly suitable for food application especially for the development of protein-enriched food commodities. Our results were found slightly higher than the study [42] where protein content ranged from $52.65 \%$ to $72.45 \%$ in seven dried fishes. Although, the protein contents differ with species to species due to some obvious factors such as the effect of spawning and migration and food availability, etc. Studies [39] [38] reported that normally the sun-dried fishes contain $60 \%$ to $80 \%$ protein. The protein contents of the developed dried fish powders are decent and the application in daily life food commodities will be the top notch to remove the low scale protein energy malnutrition.

\subsection{Fat}

The fat content of the developed dried fish powders ranged from 5.85\% to $8.04 \%$ (Table 2). The highest content of fat was found in the sample H. molitrix (8.04\%) and the lowest in A. grammepomus (5.85\%). The quantities were found (5.85, 6.65, 6.83, 8.04, and 7.17) g/100g for A. grammepomus, C. punctata, $P$. puntio, $H$. molitrix and $L$. rohita respectively. Our findings are consistent with [44] where they obtained $3.98 \%$ to $4.78 \%$ fat in 3 sun-dried fish species. Our 
Table 2. Biochemical composition analysis of the dried fish powder samples on dry basis $(\mathrm{g} / 100 \mathrm{~g})$.

\begin{tabular}{ccccccc}
\hline Fish powder Samples & Moisture $(\mathrm{g} / \mathbf{1 0 0 \mathrm { g }})$ & Protein $(\mathrm{g} / \mathbf{1 0 0 \mathrm { g }})$ & Fat $(\mathrm{g} / \mathbf{1 0 0 \mathrm { g }})$ & Ash $(\mathrm{g} / \mathbf{1 0 0 \mathrm { g }})$ & Carbohydrate $(\mathrm{g} / 100 \mathrm{~g})$ & Energy $(\mathrm{kcal} / 100 \mathrm{~g})$ \\
\hline$A G$ & $6.84 \pm 0.1^{\mathrm{a}}$ & $75.80 \pm 0.5^{\mathrm{a}}$ & $5.85 \pm 0.1^{\mathrm{a}}$ & $8.10 \pm 0.4^{\mathrm{a}}$ & $3.40 \pm 0.6^{\mathrm{a}}$ & $369.46 \pm 1.8^{\mathrm{a}}$ \\
$C P$ & $6.90 \pm 0.2^{\mathrm{a}}$ & $73.36 \pm 0.1^{\mathrm{b}}$ & $6.65 \pm 0.1^{\mathrm{a}}$ & $8.43 \pm 0.2^{\mathrm{ab}}$ & $4.66 \pm 0.2^{\mathrm{a}}$ & $371.95 \pm 0.6^{\mathrm{a}}$ \\
$P P$ & $7.23 \pm 0.1^{\mathrm{ab}}$ & $72.90 \pm 0.2^{\mathrm{b}}$ & $6.83 \pm 0.8^{\mathrm{ab}}$ & $9.19 \pm 0.1^{\mathrm{b}}$ & $3.84 \pm 0.6^{\mathrm{a}}$ & $368.47 \pm 4.9^{\mathrm{a}}$ \\
$H M$ & $7.49 \pm 0.3^{\mathrm{b}}$ & $70.80 \pm 0.2^{\mathrm{c}}$ & $8.04 \pm 0.4^{\mathrm{b}}$ & $7.66 \pm 0.3^{\mathrm{ad}}$ & $6.01 \pm 0.7^{\mathrm{b}}$ & $379.61 \pm 1.9^{\mathrm{b}}$ \\
$L R$ & $8.85 \pm 0.2^{\mathrm{c}}$ & $72.63 \pm 0.1^{\mathrm{bd}}$ & $7.17 \pm 0.7^{\mathrm{ab}}$ & $8.21 \pm 0.4^{\mathrm{ac}}$ & $8.21 \pm 0.4^{\mathrm{ac}}$ & $367.50 \pm 0.9^{\mathrm{ac}}$ \\
\hline
\end{tabular}

( AG. Awaous grammepomus, CP. Channa punctata, PP. Puntius puntio, HM: Hypophthalmichthys molitrix, LR: Labeo rohita); values (Mean $\pm \mathrm{SD}$ ) with different superscripts in columns are significantly different at $\mathrm{p}<0.05$.

study is also supported by another research [45] which revealed that sun dried indigenous Bangladeshi Channa punctatus, Amblypharyngodon mola, and Glossogobius giuris contained $4.90 \%, 19.83 \%, 7.38 \%$ of lipids and also mentioned that lipid content also varies from species to species. Fish lipid or fish oil especially omega-3 polyunsaturated fatty acids or PUFAs (EPA+DHA) occupy enormous important roles in humans and prevent several diseases and contribute to the human health and nutritional improvement throughout the life [46]. In this regard the higher content of fat portion in the dried fish powders may contribute to increase the final consumption of omega-3 polyunsaturated fatty acids since they are mostly concentrated in dry form. Finally, incorporation of these developed dried fish powders in daily life food commodities will certainly ameliorate the fish oil/lipid portion of food commodities.

\subsection{Carbohydrate (Including Fiber) and Energy (kcal/100g)}

The carbohydrate contents were calculated and mentioned as including fiber. The highest value of carbohydrate was $6.01 \%$ ( $H$. molitrix) and the lowest was $3.40 \%$ (A. grammepomus). The ranges of carbohydrate were found $3.40 \%$ to $6.01 \%$ (Table 2). In this study, the energy values of the five developed fish powders ranged from (367.50 to 379.61$) \mathrm{kcal} / 100 \mathrm{~g}$. The quantities were found (369.46, 371.95, 368.47, 379.61 and 367.50) kcal/100g for A. grammepomus, C. punctata, P. puntio, H. molitrix and L. rohita respectively. Regarding the energy values our developed dried fish powders are decent and could ameliorate the overall energy requirement of all groups of people.

\subsection{Trace Elements}

The trace element contents are presented in (Table 3). Maximum calcium content was found in sample L. rohita $(2.54 \mathrm{~g} / \mathrm{kg})$ and minimum in C. punctata as $(2.43 \mathrm{~g} / \mathrm{kg})$. The calcium quantities were found $(2.43,2.31,2.52,2.53$, and 2.54$)$ $\mathrm{g} / \mathrm{kg}$ for A. grammepomus, C. punctata, P. puntio, H. molitrix and L. rohita respectively. Calcium plays essential role in human body for the formation of bones muscle tone and nervous impulse [47]. One study reported that $\mathrm{H}$. molitrix and L. rohita fish powder contain calcium content as $2.52 \mathrm{~g} / \mathrm{kg}$ and $2.5 \mathrm{~g} / \mathrm{kg}$ respectively [11]. The highest iron content was found in $H$. molitrix $(0.15 \mathrm{~g} / \mathrm{kg})$ 
Table 3. Trace elements analysis of the dried fish powder samples on dry basis.

\begin{tabular}{|c|c|c|c|c|c|c|}
\hline Fish powder Samples & Calcium (g/kg) & Iron $(\mathrm{g} / \mathrm{kg})$ & Phosphorous $(\mathrm{g} / \mathrm{kg})$ & Cadmium $(\mu \mathrm{g} / \mathrm{kg})$ & Lead $(\mu \mathrm{g} / \mathrm{kg})$ & Arsenic $(\mu \mathrm{g} / \mathrm{kg})$ \\
\hline$A G$ & $2.43 \pm 0.04^{\mathrm{ab}}$ & $0.04 \pm 0.00^{\mathrm{a}}$ & $1.13 \pm 0.25^{\mathrm{ac}}$ & $3.98 \pm 0.13^{\mathrm{acd}}$ & $12.39 \pm 0.16^{\mathrm{a}}$ & ND \\
\hline$C P$ & $2.31 \pm 0.04^{\mathrm{a}}$ & $0.07 \pm 0.00^{\text {ad }}$ & $0.73 \pm 0.21^{\mathrm{a}}$ & $3.97 \pm 0.14^{\mathrm{ac}}$ & $10.60 \pm 0.33^{b}$ & ND \\
\hline$P P$ & $2.52 \pm 0.07^{\mathrm{b}}$ & $0.13 \pm 0.01^{\mathrm{b}}$ & $1.20 \pm 0.10^{\mathrm{bc}}$ & $2.94 \pm 0.39^{\mathrm{bd}}$ & $9.51 \pm 0.15^{\mathrm{c}}$ & ND \\
\hline$H M$ & $2.53 \pm 0.03^{\mathrm{b}}$ & $0.15 \pm 0.01^{\mathrm{bc}}$ & $0.93 \pm 0.15^{\mathrm{ab}}$ & $4.30 \pm 0.21^{\mathrm{c}}$ & $14.47 \pm 0.30^{\mathrm{d}}$ & ND \\
\hline$L R$ & $2.54 \pm 0.07^{\mathrm{b}}$ & $0.09 \pm 0.01^{\mathrm{d}}$ & $1.40 \pm 0.10^{c}$ & $3.35 \pm 0.26^{\mathrm{d}}$ & $13.10 \pm 0.26^{\mathrm{e}}$ & $1.27 \pm 0.08$ \\
\hline
\end{tabular}

(AG: Awaous grammepomus, CP. Channa punctata, PP: Puntius puntio, HM: Hypophthalmichthys molitrix, LR: Labeo rohita); values (Mean \pm SD) with different superscripts in columns are significantly different at $\mathrm{p}<0.05 ; \mathrm{ND}=$ Not Detected.

and minimum in $A$. grammepomus $(0.13 \mathrm{~g} / \mathrm{kg})$. The iron quantities were found (0.04, 0.07, 0.13, 0.15, and 0.09) g/kg for A. grammepomus, C. punctata, P. puntio, $H$. molitrix and L. rohita respectively. One study [39] found that the iron content was ranged from $16.85 \mathrm{mg} / 100 \mathrm{~g}$ fish (O. bacaila) to $45.20 \mathrm{mg} / 100 \mathrm{~g}$ fish (mixed species). Another study [48] reported that iron was present at a range from $1.71 \mathrm{mg} / 100 \mathrm{~g}$ to $8.00 \mathrm{mg} / 100 \mathrm{~g}$ of Some Smoke-dried Hill Stream Fishes from Manipur, India; this discrepancy could be attributed to the factors affecting the iron content; such as species, individuals, and sampling period [49]. As for the phosphorous content the L. rohita was found the highest $(1.4 \mathrm{~g} / \mathrm{kg})$ and the lowest in C. punctata $(0.73 \mathrm{~g} / \mathrm{kg})$. The phosphorous quantities were found (1.13, $0.73,1.20,0.93$, and 1.40$) \mathrm{g} / \mathrm{kg}$ for A. grammepomus, C. punctata, P. puntio, $H$. molitrix and L. rohita respectively. Study [41] showed that such variation in concentrations of mineral elements from one species to another was due to the chemical forms of the elements and their concentrations in the local environment. Phosphorus is one of the most important minerals in human physiology, possessing functions such as structural integrity in bones and teeth, cell signaling, and blood bufferin [47]. Another study [43] reported that Burrito fish (Brachydeuterus auritus) contains $93.71 \mathrm{mg} / 100 \mathrm{~g}$ phosphorus which is near to the present study. For the heavy metal analysis some common heavy metals such as cadmium, lead and arsenic were studied which have been investigated by many research investigation for possible onset of adverse effects on health. The $\mathrm{Pb}, \mathrm{Cd}$ and As contents were ranged from ( 9.51 to $14.47 \mu \mathrm{g} / \mathrm{kg}),(2.94$ to $4.30 \mu \mathrm{g} / \mathrm{kg}$ ) and $(0.00$ to $1.27 \mu \mathrm{g} / \mathrm{kg}$ ) respectively. The highest content of $\mathrm{Pb}$ was found in the sample H. molitrix $(14.47 \mu \mathrm{g} / \mathrm{kg})$ and the lowest in P. puntio $(9.51 \mu \mathrm{g} / \mathrm{kg})$. The lead quantities were found $(12.39,10.60,9.51,14.47$, and 13.10) $\mu \mathrm{g} / \mathrm{kg}$ for $A$. grammepomus, $C$. punctata, $P$. puntio, $H$. molitrix and $L$. rohita respectively. The highest content of Cd was found in the sample H. molitrix $(4.30 \mu \mathrm{g} / \mathrm{kg})$ and the lowest in $P$. puntio $(2.94 \mu \mathrm{g} / \mathrm{kg})$. The cadmium quantities were found $(3.98$, 3.97, 2.94, 4.30, and 3.35) $\mu \mathrm{g} / \mathrm{kg}$ for A. grammepomus, C. punctata, P. puntio, H. molitrix and L. rohita respectively.

Likewise, for the arsenic contents the highest was found in L. rohita (1.27 $\mu \mathrm{g} / \mathrm{kg}$ ) and no other dried fish powder samples were detected for arsenic con- 
tent. Heavy metals are usually transfer to human body through the food chain when wide range of organic and inorganic substances are released into aquatic systems leading to bioaccumulation which then found to be responsible for their different toxicity [50]. There have been various studies on the heavy metals such as cadmium, lead and arsenic levels in dried fish samples from different freshwater ecosystems [51]. Study revealed out that lead and cadmium are responsible for much adverse condition in body such as kidney damage, renal disorder, and high blood pressure, and bone fracture, gastrointestinal, reproductive and circulatory changes. In addition, Human body have reported to have nausea and vomiting at a level of $15 \mathrm{mg} / \mathrm{L}$ of cadmium [52]. In our investigation we found that all of these heavy metals were below the recommended tolerable limit proposed by WHO/FAO expert [53]. Moreover, arsenic was detected in only the sample $L$. rohita and no other samples were detected for arsenic content. A similar study has been conducted by Reyahi-Khoram who found that concentration of $\mathrm{Cd}$ and $\mathrm{Pb}$ in the dry muscle and liver tissues were $3.67 \mu \mathrm{g} / \mathrm{kg}$ and 12.82 $\mu \mathrm{g} / \mathrm{kg}$, which is mostly similar to our investigation. [50] Another study detected the cadmium in Channa puncta dry samples where the content was found 9.8 $\mu \mathrm{g} / \mathrm{kg}$ of sample [54]. From food safety point of view, $\mathrm{Pb}, \mathrm{Cd}$, and As contents remain below the respective recommended limit which indicate the newly developed dried fish powder samples are safe for consumption. However, heavy metal concentrations are increasing enormously which could be attributed to the excessive use of pesticides and inorganic fertilizers in agricultural activities near aquatic resources. To facilitate safe aquatic food resources, it is an urgent task to maintain a healthy ecosystem while restricting profuse utilization of organic and inorganic substances such as fertilizer and pesticides.

\subsection{Total Viable Count (TVC)}

Total viable count (TVC) of the fish samples during the 90 days period were

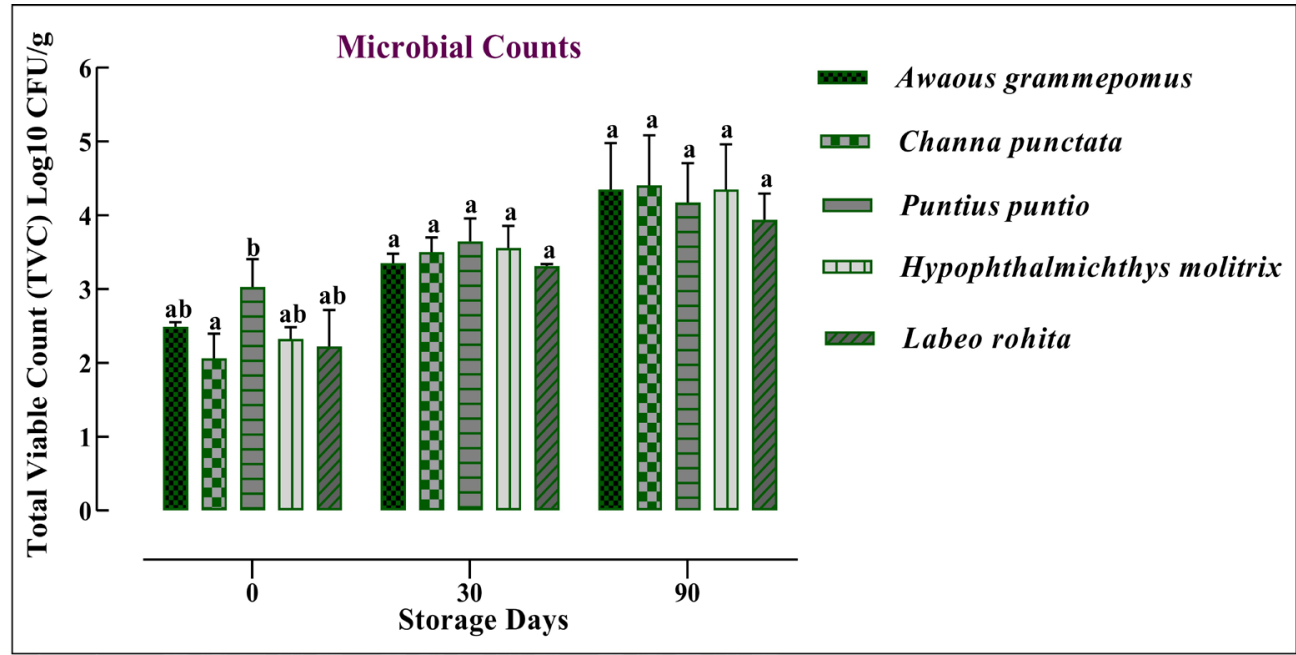

Figure 3. Changes in Total Viable Count (TVC) of the dried fish powder samples during 90 days storage period $(\log 10 \mathrm{CFU} / \mathrm{g})$; values (Mean $\pm \mathrm{SD}$ ) with different superscripts are significantly different at $\mathrm{p}<0.05$. 
presented on the (Figure 3 ). The results were presented as $\log 10 \mathrm{CFU} / \mathrm{g}$. The highest bacterial load (4.40 $\log 10 \mathrm{CFU} / \mathrm{g})$ was found in C. punctata sample and the lowest $(3.94 \log 10 \mathrm{CFU} / \mathrm{g})$ in the L. rohita sample at the end of 90 days period. At $0^{\text {th }}$ days the counts were between ranges (3.03 to $2.06 \log 10 \mathrm{CFU} / \mathrm{g}$ ). At $30^{\text {th }}$ days TVC reveals that the lowest increase of viable counts was found in the sample L. rohita $(3.31 \log 10 \mathrm{CFU} / \mathrm{g})$ and the highest increase in the sample $P$. puntio (3.03 $\log 10 \mathrm{CFU} / \mathrm{g}$ ). Our study found that, the lowest increase of microbial load was due to the low moisture contents in all the dried fish powder samples. The shelf-life of fish is generally restricted and affected due to the growth of Gram-negative microorganisms such as Pseudomonas, Shewanella putrefaciens, and Aeromonas under aerobic condition and anaerobic condition and their invasion is the main organism responsible for deterioration of food protein, fats and other quality attributes [55] [56]. In our investigation we found that all samples studied were in the range of acceptable limit as recommended [56], therefore it is apparent that these newly developed dried fish powders can be used safely up to 3 months during room temperature $\left(27^{\circ} \mathrm{C}-30^{\circ} \mathrm{C}\right)$ storage.

\section{8. $\mathrm{pH}$}

$\mathrm{pH}$ was assessed during 90 days period (Table 4). The $\mathrm{pH}$ changes during 90 days period were in the range of (5.53 to 7.20), (5.30 to 6.97), (5.77 to 7.87), (6.30 to 7.60 ) and (6.37 to 8.17) for A. grammepomus, C. punctata, P. puntio, H. molitrix and $L$. rohita samples during 90 days of storage period. Highest $\mathrm{pH}$ during the 90 days period was found in the sample L. rohita (8.17) and the lowest content in the sample $C$. punctata (5.30). A similar study conducted by (M. Nurullah et al. 2007) reported the changes in $\mathrm{pH}$ content of cured and uncured dried in different market channels ranges was found between 5.8 to 7.00 which are slightly lower than our investigation [57]. However, during the post-mortem period of fishes, decomposition of nitrogenous compounds occurs and leads to an elevation in $\mathrm{pH}$ in the fish flesh. In addition, the elevation in $\mathrm{pH}$ indicates the loss of quality and most microorganisms grow the best at $\mathrm{pH}$ values between 6.6 and 7.5 [58] [59]. While the $\mathrm{pH}$ value of fish products in the range of 6.8 to 7.0 is

Table 4. Changes in $\mathrm{pH}$, Peroxide Values (PV) and Moisture Reconstitutions (g/100g) of the dried fish powder samples during 90 days room temperature $\left(27^{\circ} \mathrm{C}-30^{\circ} \mathrm{C}\right)$ storage period.

\begin{tabular}{|c|c|c|c|c|c|c|c|c|c|}
\hline \multirow{2}{*}{$\begin{array}{l}\text { Fish powder } \\
\text { Samples }\end{array}$} & \multicolumn{3}{|c|}{$\mathrm{pH}$} & \multicolumn{3}{|c|}{$\mathrm{PV}$ (mEq of $\mathrm{O}^{2} / \mathrm{kg}$ of fat) } & \multicolumn{3}{|c|}{ Moisture Reconstitution (g/100g) } \\
\hline & $0^{\text {th }}$ day & $30^{\text {th }}$ day & $90^{\text {th }}$ day & $0^{\text {th }}$ day & $30^{\text {th }}$ day & $90^{\text {th }}$ day & $0^{\text {th }}$ day & $30^{\text {th }}$ day & $90^{\text {th }}$ day \\
\hline AG & $5.5 \pm 0.2^{\mathrm{a}}$ & $6.4 \pm 0.3^{\mathrm{ab}}$ & $7.2 \pm 0.3^{\mathrm{ab}}$ & $8.6 \pm 0.2^{\mathrm{a}}$ & $9.2 \pm 0.3^{\mathrm{a}}$ & $12.9 \pm 0.5^{\mathrm{a}}$ & $6.8 \pm 0.1^{\mathrm{a}}$ & $7.4 \pm 0.5^{\mathrm{a}}$ & $10.7 \pm 0.2^{\mathrm{a}}$ \\
\hline$C P$ & $5.3 \pm 0.4^{\mathrm{a}}$ & $5.7 \pm 0.5^{\mathrm{a}}$ & $6.9 \pm 0.2^{\mathrm{b}}$ & $9.1 \pm 0.2^{\mathrm{a}}$ & $10.5 \pm 0.3^{\mathrm{ab}}$ & $15.7 \pm 0.5^{\mathrm{bc}}$ & $6.9 \pm 0.2^{\mathrm{a}}$ & $7.9 \pm 0.2^{\mathrm{ab}}$ & $11.8 \pm 0.9^{\mathrm{ac}}$ \\
\hline$P P$ & $5.8 \pm 0.2^{\mathrm{a}}$ & $6.6 \pm 0.5^{\mathrm{ab}}$ & $7.9 \pm 0.4^{\mathrm{ac}}$ & $9.2 \pm 0.3^{\mathrm{a}}$ & $9.6 \pm 0.7 \mathrm{a}$ & $14.3 \pm 0.7^{\mathrm{a}}$ & $7.2 \pm 0.1^{\mathrm{a}}$ & $9.2 \pm 0.4^{\mathrm{bc}}$ & $12.8 \pm 0.3^{\mathrm{bc}}$ \\
\hline $\mathrm{HM}$ & $6.3 \pm 0.5^{\mathrm{a}}$ & $6.8 \pm 0.3^{\mathrm{b}}$ & $7.6 \pm 0.3^{\mathrm{abc}}$ & $10.7 \pm 0.5^{\mathrm{b}}$ & $11.3 \pm 0.4^{\mathrm{b}}$ & $16.2 \pm 0.3^{c}$ & $7.5 \pm 0.3^{\mathrm{a}}$ & $8.8 \pm 0.4^{\mathrm{b}}$ & $12.1 \pm 0.6^{\mathrm{c}}$ \\
\hline$L R$ & $6.4 \pm 0.6^{\mathrm{a}}$ & $7.4 \pm 0.2^{\mathrm{b}}$ & $8.2 \pm 0.3^{c}$ & $11.6 \pm 0.4^{\mathrm{b}}$ & $12.5 \pm 0.6^{\mathrm{b}}$ & $16.8 \pm 0.8^{c}$ & $9 \pm 0.4^{\mathrm{b}}$ & $9.8 \pm 0.4^{c}$ & $13.8 \pm 0.4^{\mathrm{d}}$ \\
\hline
\end{tabular}

(AG: Awaous grammepomus, CP. Channa punctata, PP: Puntius puntio, HM: Hypophthalmichthys molitrix, LR: Labeo rohita); values (Mean \pm SD) with different superscripts in columns are significantly different at $\mathrm{p}<0.05$. 
usually the limit of acceptability, it is considered to be spoiled above $7.0 \mathrm{of} \mathrm{pH}$ [60] [61]. In our investigation we found that all of the samples were in the acceptable range at the end of 30 days period except for $L$. rohita where a slight increase in $\mathrm{pH}$ was detected. However, at the end of 90 days storage period the $\mathrm{pH}$ elevation was near around acceptable limit except for L. rohita which elevated up to 8.17. Study on changes in $\mathrm{pH}$ value of Sun-dried-salted (SDS) and Turmeric treated Sun-dried-Salted (SDS+T) Shoal fish during storage at room temperature revealed that the $\mathrm{pH}$ elevation during 180 days of storage period was ranged from 6.2 to 8.3 which is mostly similar to our findings [62].

\subsection{Peroxide Values}

Peroxide values were assessed during 90 days period (Table 4). The peroxide value changes during 90 days period were in the range of (8.60 to $12.97 \mathrm{mEq}$ $\mathrm{O}^{2} / \mathrm{kg}$ of fat), (9.13 to $15.73 \mathrm{mEq} \mathrm{O}^{2} / \mathrm{kg}$ of fat), (9.17 to $14.33 \mathrm{mEq} \mathrm{O} / \mathrm{kg}$ of fat), (10.73 to $16.23 \mathrm{mEq} \mathrm{O} / \mathrm{kg}$ of fat) and ( 11.63 to $16.77 \mathrm{mEq} \mathrm{O} / \mathrm{kg}^{2}$ of fat) for $A$. grammepomus, $C$. punctata, $P$. puntio, $H$. molitrix and $L$. rohita samples during 90 days of storage period. Highest peroxide value during the 90 days period was found in the sample L. rohita $\left(16.77 \mathrm{mEq} \mathrm{O}^{2} / \mathrm{kg}\right.$ of fat) and the lowest content in the sample $A$. grammepomus $\left(8.60 \mathrm{mEq} \mathrm{O}^{2} / \mathrm{kg}\right.$ of fat). A study found that the peroxide value ( $\mathrm{mEq} \mathrm{O}^{2} / \mathrm{kg}$ of fat) of cured and uncured dried in different market channels were found $6.3 \mathrm{mEq} \mathrm{O} / \mathrm{kg}$ of fat to $16.6 \mathrm{mEq} \mathrm{O} / \mathrm{kg}$ of fat which is mostly similar to our investigation [57]. The peroxide value which is used as primary indicator of oxidation of fat (rancidity) elevated during marketing process from dry fish processor to wholesale and wholesale to retail with storage time in both cured and uncured dried fish. Studies [57] [63] [64] reported that when peroxide value is above $10-20 \mathrm{mEq}$ of $\mathrm{O}^{2} / \mathrm{kg}$ of fat, fish develop rancid taste and smell. However, in all of the samples studied the peroxide value contents were in the acceptable limit according to the recommended level described [57] [63] [65]. Fat oxidation is a self-catalyzing reaction, which is exaggerated by the age of the raw material as well as oxidation of fats during processing and storage. The lipid quality of the anchovies (Stolephoru ss $p$.) was investigated and the result showed gradual increase in peroxide value from 3.2 to $24.5 \mathrm{mEq}$ of $\mathrm{O}^{2} / \mathrm{kg}$ of fat during 5 weeks of storage period [66].

\subsection{Moisture Reconstitutions}

Moisture reconstitutions were assessed during 90 days period (Table 4). The moisture changes during 90 days period were in the range of (6.84 to 10.67 $\mathrm{g} / 100 \mathrm{~g}),(7.93$ to $11.83 \mathrm{~g} / 100 \mathrm{~g}),(9.17$ to $12.8 \mathrm{~g} / 100 \mathrm{~g}),(8.77$ to $12.13 \mathrm{~g} / 100 \mathrm{~g})$ and (9.83 to $13.83 \mathrm{~g} / 100 \mathrm{~g}$ ) for $A$. grammepomus, $C$. punctata, $P$. puntio, $H$. molitrix and $L$. rohita samples. Highest moisture reconstitution during the 90 days period was found in the sample L.rohita $(13.83 \mathrm{~g} / 100 \mathrm{~g})$ and lowest content in the sample A. grammepomus (10.67 g/100g). A similar study conducted by (M. Nurullah et al. 2007) reported the changes in moisture content of the solar dried SIS 
(small indigenous species) product in packaging condition during 90 days of storage where an average the initial moisture content was in the range of $13.5 \%$ to $15.0 \%$ and at the end of 90 days storage period the moisture content increased to in the range of $22.9 \%$ to $24 \%$ which is higher than the recommended limit of $16 \%$ for dried fishery products [67]. The moisture content appear to be a precise indicator of the susceptibility of a product to undergo microbial spoilage since elevation of moisture content during storage can create favorable condition for microbes to grow up and propagate [68] [69]. All of the samples studied for moisture uptake were found to be in the range of acceptable limit [67] [70].

\subsection{Sensory Evaluation}

In this study, sensory scores of developed dried fish powders with regard to appearance, texture, odor, and overall acceptability were found to be highly acceptable (Table 5). The results reveal that all the samples were up to the standard value at $0^{\text {th }}$ day. Subtle decline in the dried fish powders samples were observed at $30^{\text {th }}$ day. Among all the powders A. grammepomus, C. punctata and P. puntio samples mostly retained the sensorial qualities and found to be highly acceptable at the end of 90 days storage period. All the samples were found up to the minimum limit of acceptable sensorial recommendation [37] at the end of 90 days room temperature $\left(27^{\circ} \mathrm{C}-30^{\circ} \mathrm{C}\right)$ storage.

Sensory evaluation of food components is important to categorize the exact superiority and consumer acceptability of a particular food or food product. Sensory evaluation of food is considered as a scientific method used to address, measure, peruse and interpret responses to products as perceived through the senses of sight, touch, smell, taste, and hearing. In this study, we found that the sensory parameters have significant effects on the developed dried fish powders and have better sensory characteristics. Appearance, texture, odor, and overall acceptability are some of the obvious perception of eye perceived by the consumers and considered as the main criteria for the evaluation of consumer acceptance analysis of the developed fish powders during 90 days of storage.

Table 5. Changes in sensorial attributes of the dried fish powder samples during 90 days room temperature $\left(27^{\circ} \mathrm{C}-30^{\circ} \mathrm{C}\right)$ storage period.

\begin{tabular}{|c|c|c|c|c|c|c|c|c|c|c|c|c|}
\hline \multirow{2}{*}{$\begin{array}{c}\text { Fish } \\
\text { powder } \\
\text { Samples }\end{array}$} & \multicolumn{3}{|c|}{ Appearance } & \multicolumn{3}{|c|}{ Odor } & \multicolumn{3}{|c|}{ Texture } & \multicolumn{3}{|c|}{ Overall Acceptability } \\
\hline & $0^{\text {th }}$ day & $30^{\text {th }}$ day & $90^{\text {th }}$ day & $0^{\text {th }}$ day & $30^{\text {th }}$ day & $90^{\text {th }}$ day & $0^{\text {th }}$ day & $30^{\text {th }}$ day & $90^{\text {th }}$ day & $0^{\text {th }}$ day & $30^{\text {th }}$ day & $90^{\text {th }}$ day \\
\hline AG & $7.8 \pm 0.5^{\mathrm{a}}$ & $6.7 \pm 0.7^{\mathrm{ab}}$ & $5.9 \pm 0.9^{\mathrm{ab}}$ & $7.8 \pm 0.6^{\mathrm{a}}$ & $7.3 \pm 0.8^{\mathrm{a}}$ & $5.8 \pm 0.6^{\mathrm{a}}$ & $7.0 \pm 1.3^{\mathrm{a}}$ & $7.1 \pm 1.3^{\mathrm{a}}$ & $6.5 \pm 0.8^{\mathrm{a}}$ & $7.5 \pm 0.3^{\mathrm{a}}$ & $6.5 \pm 0.3^{\mathrm{a}}$ & $5.9 \pm 0.2^{\mathrm{a}}$ \\
\hline$C P$ & $7.9 \pm 0.7^{\mathrm{ab}}$ & $7.1 \pm 0.4^{\mathrm{a}}$ & $6.2 \pm 0.6^{\mathrm{a}}$ & $7.7 \pm 0.4^{\mathrm{a}}$ & $7.3 \pm 0.4^{\mathrm{a}}$ & $4.9 \pm 0.7^{\mathrm{ab}}$ & $6.2 \pm 0.6^{\mathrm{a}}$ & $6.2 \pm 0.6^{\mathrm{a}}$ & $5.8 \pm 0.8^{\mathrm{a}}$ & $7.7 \pm 0.7^{\mathrm{a}}$ & $6.3 \pm 0.8^{\mathrm{a}}$ & $5.9 \pm 0.6^{\mathrm{a}}$ \\
\hline$P P$ & $6.4 \pm 0.8^{\mathrm{b}}$ & $6.0 \pm 0.8^{\mathrm{b}}$ & $5.6 \pm 0.7^{\mathrm{abc}}$ & $7.6 \pm 0.7^{\mathrm{a}}$ & $6.0 \pm 0.9^{\mathrm{ab}}$ & $5.3 \pm 0.4^{\mathrm{ab}}$ & $6.4 \pm 0.4^{\mathrm{a}}$ & $6.1 \pm 1^{\mathrm{a}}$ & $5.7 \pm 0.8^{\mathrm{ab}}$ & $7.4 \pm 0.4^{\mathrm{a}}$ & $6.5 \pm 0.7^{\mathrm{a}}$ & $6.0 \pm 0.5^{\mathrm{a}}$ \\
\hline $\mathrm{HM}$ & $6.6 \pm 0.4^{\mathrm{b}}$ & $6.1 \pm 0.4^{\mathrm{ab}}$ & $4.6 \pm 0.8 b^{c}$ & $7.0 \pm 0.8^{\mathrm{a}}$ & $5.7 \pm 0.7^{\mathrm{b}}$ & $4.3 \pm 1^{\mathrm{b}}$ & $7.3 \pm 0.5^{\mathrm{a}}$ & $7.0 \pm 0.3^{\mathrm{a}}$ & $6.2 \pm 0.9^{\mathrm{a}}$ & $7.7 \pm 0.7^{\mathrm{a}}$ & $6.1 \pm 0.6^{\mathrm{a}}$ & $5.6 \pm 0.4^{\mathrm{a}}$ \\
\hline$L R$ & $6.7 \pm 0.3^{\mathrm{ab}}$ & $5.7 \pm 0.3^{\mathrm{b}}$ & $4.4 \pm 0.7^{\mathrm{c}}$ & $6.9 \pm 0.9^{\mathrm{a}}$ & $4.8 \pm 0.6^{\mathrm{b}}$ & $4.2 \pm 0.6^{\mathrm{b}}$ & $5.5 \pm 0.8^{\mathrm{b}}$ & $4.9 \pm 0.7^{\mathrm{b}}$ & $4.3 \pm 0.5^{\mathrm{b}}$ & $7.2 \pm 0.7^{\mathrm{a}}$ & $5.9 \pm 0.4^{\mathrm{a}}$ & $5.3 \pm 0.6^{\mathrm{a}}$ \\
\hline
\end{tabular}

(AG. Awaous grammepomus, CP. Channa punctata, PP. Puntius puntio, HM: Hypophthalmichthys molitrix, LR: Labeo rohita); values (Mean $\pm \mathrm{SD}$ ) with different superscripts in columns are significantly different at $\mathrm{p}<0.05$. 


\section{Conclusion}

On the basis of nutritional, microbial and sensory evaluation, the newly developed fish powders are inundated with nutrients thereby we expect that inclusion can be efficacious to ameliorate the functional property of daily life food products. The slightest moisture reconstitution, $\mathrm{pH}$, and peroxide value elevation during 90 days room temperature storage period reveal that the powders have robust shelf-life. On the microbiological point of view, the microbial loads at the end of 90 days storage period were in acceptable limit; therefore, these dried fish powders are standard and safe for consumption up to 3 months. It is also significant to clarify that these powders are particularly high in protein, ash, fiber, fat and energy value which make the presently developed powders an appropriate choice for the fulfillment of nutritional demands and could play a great role in alleviating the protein energy malnutrition; therefore, It can be a good source of valueadded food components for commercial processed foods production.

\section{Acknowledgements}

The authors gratefully acknowledge the contribution of Md Torikul Islam, a Ph.D. student in Nutrition \& Integrative Physiology at the University of Utah, The USA for his valuable assistance and guidelines throughout the research investigation.

\section{Funding}

This work is not supported by any research funding.

\section{Conflicts of Interest}

The authors declare no conflicts of interest regarding the publication of this paper.

\section{Authors' Contributions}

Niaz Mahmud, Shahriar Islam Satya and Md. Shovon Al-Fuadconceptualized and designed the work; Niaz Mahmud did the literature reviews and wrote the paper; Md Adnan Karim, Md. Abdullah Al Mamun, Md. JannatulFerdaus and Suzon Ahmed recorded the data and analyzed; Md. Shofiqul Islam and NazmusSakib assisted in microbial analysis; Monirul Islam and Mst. JuiYeasmin critically reviewed the manuscript and were associated with the edition of the paper. All authors read and approved the final manuscript.

\section{References}

[1] FAO (2000) The State of World Fisheries and Aquaculture. Rome.

[2] Islam, M., Sarker, M.N.I., Islam, M.S., Prabakusuma, A.S., Mahmud, N., Fang, Y. and Xia, W. (2018) Development and Quality Analysis of Protein Enriched Instant Soup Mix. Food and Nutrition Sciences, 9, 663-675. https://doi.org/10.4236/fns.2018.96050 
[3] Belton, B. and Thilsted, S.H. (2014) Fisheries in Transition: Food and Nutrition Security Implications for the Global South. Global Food Security, 3, 59-66. https://doi.org/10.1016/j.gfs.2013.10.001

[4] Bogard, J.R., Thilsted, S.H., Marks, G.C., Wahab, M.A., Hossain, M.A., Jakobsen, J. and Stangoulis, J. (2015) Nutrient Composition of Important Fish Species in Bangladesh and Potential Contribution to Recommended Nutrient Intakes. Journal of Food Composition and Analysis, 42, 120-133.

https://doi.org/10.1016/j.jfca.2015.03.002

[5] Shaheen, N., Rahim, A.T.M.R., Mohiduzzaman, M., Banu, C.P., Bari, M.L., Tukun, A.B., Stadlmayr, B., et al. (2013) Food Composition Table for Bangladesh. Final Research Results, 187.

[6] Monteiro, M.L.G., Mársico, E.T., Lázaro, C.A., Ribeiro, R.O., Jesus, R.S. and Conte-Júnior, C.A. (2014) Flours and Instant Soup from Tilapia Waste as Healthy Alternatives to the Food Industry. Food Science and Technology Research, 20, 571-581. https://doi.org/10.3136/fstr.20.571

[7] Fitzpatrick, J.J. and Ahrné, L. (2005) Food Powder Handling and Processing: Industry Problems, Knowledge Barriers and Research Opportunities. Chemical Engineering and Processing. Process Intensification, 44, 209-214.

https://doi.org/10.1016/j.cep.2004.03.014

[8] de Freitas Eduardo, M. and da Silva Lannes, S.C. (2007) Use of Texture Analysis to Determine Compaction Force of Powders. Journal of Food Engineering, 80, 568-572. https://doi.org/10.1016/j.jfoodeng.2006.06.011

[9] Park, S.H., Lim, H.S. and Hwang, S.Y. (2012) Evaluation of Antioxidant, Rheological, Physical and Sensorial Properties of Wheat Flour Dough and Cake Containing Turmeric Powder. Food Science and Technology International, 18, 435-443. https://doi.org/10.1177/1082013211428220

[10] Hager, A.S., Wolter, A., Jacob, F., Zannini, E. and Arendt, E.K. (2012) Nutritional Properties and Ultra-Structure of Commercial Gluten Free Flours from Different Botanical Sources Compared to Wheat Flours. Journal of Cereal Science, 56, 239-247. https://doi.org/10.1016/j.jcs.2012.06.005

[11] Jahan, S.N., Bayezid, M.A., Islam, B., Siddique, M.A.B., Karmakar, P.K. and Flowra, F.A. (2017) Biochemical Quality Assessment of Fish Powder. American Journal of Food and Nutrition, 5, 110-114. https://doi.org/10.12691/ajfn-5-3-6

[12] Jeyasanta, K.I., Aiyamperumal, V. and Patterson, J. (2013) Utilization of Trash Fishes as Edible Fish Powder and Its Quality Characteristics and Consumer Acceptance. World Journal of Dairy \& Food Sciences, 8, 1-10.

[13] Sathivel, S. and Bechtel, P.J. (2006) Properties of Soluble Protein Powders from Alaska Pollock (Theragra chalcogramma). International Journal of Food Science \& Technology, 41, 520-529. https://doi.org/10.1111/j.1365-2621.2005.01101.x

[14] Sathivel, S. and Bechtel, P.J. (2008) A Comparison of Physical and Rheologic Properties of Arrowtooth Flounder Protein Made Using Three Different Extracting Processes. Journal of Food Biochemistry, 32, 557-575. https://doi.org/10.1111/j.1745-4514.2008.00184.x

[15] Krishnan, M. and Prabhasankar, P. (2012) Health Based Pasta: Redefining the Concept of the Next Generation Convenience Food. Critical Reviews in Food Science and Nutrition, 52, 9-20. https://doi.org/10.1080/10408398.2010.486909

[16] Chukwu, O. and Shaba, I.M. (2009) Effects of Drying Methods on Proximate Compositions of Catfish (Clarias gariepinus). World Journal of Agricultural Sciences, 5, 114-116. 
[17] Hilbig, C.C., Fockink, D.H., Maluf, M.L.F., Boscolo, W.R. and Feiden, A. (2013) Resistência do couro de tilápia e composição centesimal da pele nas operações de ribeira e curtimento. Scientia Agraria Paranaensis, 12, 258-266. https://doi.org/10.18188/1983-1471/sap.v12n4p258-266

[18] Modibbo, U.U., Osemeahon, S.A., Shagal, M.H. and Halilu, M. (2014) Effect of Moisture Content on the Drying Rate Using Traditional Open Sun and Shade Drying of Fish from Njuwa Lake in North Eastern Nigeria. Journal of Applied Chemistry, 7, 41-45. https://doi.org/10.9790/5736-07114145

[19] Lakra, W.S., Mohindra, V. and Lal, K.K. (2007) Fish Genetics and Conservation Research in India: Status and Perspectives. Fish Physiology and Biochemistry, 33, 475-487. https://doi.org/10.1007/s10695-007-9168-Z

[20] Sulieman, H.A. and Sidahmed, M.A. (2012) Effect of Drying System on Chemical and Physical Attributes of Dried Catfish Meat (Clarias Sp.) Worlds Veterinary Journal, 2, 1-4.

[21] Idah, P.A. and Nwankwo, I. (2013) Effects of Smoke-Drying Temperatures and Time on Physical and Nutritional Quality Parameters of Tilapia (Oreochromis niloticus). International Journal of Fisheries and Aquaculture, 5, 29-34.

[22] Sengar, S.H., Khandetod, Y.P. and Mohod, A.G. (2009) Low Cost Solar Dryer for Fish. African Journal of Environmental Science and Technology, 3, 265-271.

[23] Ojutiku, R.O., Kolo, R.J. and Mohammed, M.L. (2009) Comparative Study of Sun Drying and Solar Tent Drying of Hyperopisus bebeoccidentalis. Pakistan Journal of Nutrition, 8, 955-957. https://doi.org/10.3923/pjn.2009.955.957

[24] AOAC (2003) Official Methods of Analysis of Association of Analytical Chemist. 17th Edition, AOAC, Gaithersburg.

[25] El-Sohaimy, S.A., Shehata, M.G., Mehany, T. and Zeitoun, M.A. (2019) Nutritional, Physicochemical, and Sensorial Evaluation of Flat Bread Supplemented with Quinoa Flour. International Journal of Food Science, 2019, Article ID: 4686727. https://doi.org/10.1155/2019/4686727

[26] Farzana, T. and Mohajan, S. (2015) Effect of Incorporation of Soy Flour to Wheat Flour on Nutritional and Sensory Quality of Biscuits Fortified with Mushroom. Food Science \& Nutrition, 3, 363-369. https://doi.org/10.1002/fsn3.228

[27] Bligh, E.G. and Dyer, W.J. (1959) A Rapid Method of Total Lipid Extraction and Purification. Canadian Journal of Biochemistry and Physiology, 37, 911-917. https://doi.org/10.1139/059-099

[28] Welch, M.W., Hamar, D.W. and Fettman, M.J. (1990) Method Comparison for Calcium Determination by Flame Atomic Absorption Spectrophotometry in the Presence of Phosphate. Clinical Chemistry, 36, 351-354.

[29] Kumar, M.S., Galil, M.S.A., Suresha, M.S., Sathish, M.A. and Nagendrappa, G. (2007) A Simple Spectrophotometric Determination of Phosphate in Sugarcane Juices, Water and Detergent Samples. Journal of Chemistry, 4, 467-473. https://doi.org/10.1155/2007/576560

[30] Mansur, M.A., Rahman, S., Khan, M.N.A., Reza, M.S. and Uga, S. (2013) Study on the Quality and Safety Aspect of Three Sun-Dried Fish. African Journal of Agricultural Research, 8, 5149-5155.

[31] Eboh, L., Mepba, H.D. and Ekpo, M.B. (2006) Heavy Metal Contaminants and Processing Effects on the Composition, Storage Stability and Fatty Acid Profiles of Five Common Commercially Available Fish Species in Oron Local Government, Nigeria. Food Chemistry, 97, 490-497. 
https://doi.org/10.1016/j.foodchem.2005.05.041

[32] Al Mamun, S., Das, K.K. and Uddin, M.A. (2016) Microbiological Analysis and Determination of Antibacterial Activity of Apple Samples Collected from Local Markets in Dhaka City, Bangladesh. Stamford Journal of Microbiology, 6, 11-15. https://doi.org/10.3329/sjm.v6i1.33511

[33] Chowdhury, C.R., Shahnawaz, K., Kumari, D.P., Chowdhury, A., Gootveld, M. and Lynch, E. (2018) Highly Acidic pH Values of Carbonated Sweet Drinks, Fruit Juices, Mineral Waters and Unregulated Fluoride Levels in Oral Care Products and Drinks in India: A Public Health Concern. Perspectives in Public Health, 139, 186-194. https://doi.org/10.1177/1757913918787218

[34] Siddique, A. and Park, Y.W. (2018) Evaluation of Correlation between Acid Degree Value and Peroxide Value in Lipolysis of Control and Iron Fortified Caprine Milk Cheeses during 4 Months Storage. Open Journal of Animal Sciences, 9, 1-11. https://doi.org/10.4236/ojas.2019.91001

[35] Farzana, T., Mohajan, S., Saha, T., Hossain, M.N. and Haque, M.Z. (2017) Formulation and Nutritional Evaluation of a Healthy Vegetable Soup Powder Supplemented with Soy Flour, Mushroom, and Moringa Leaf. Food Science \& Nutrition, 5, 911-920. https://doi.org/10.1002/fsn3.476

[36] Bisla, G., Choudhary, S. and Chaudhary, V. (2014) Evaluation of the Nutritive and Organoleptic Values of Food Products Developed by Incorporated Catharanthus roseus (Sadabahar) Fresh Leaves Explore Their Hypoglycemic Potential. The Scientific World Journal, 2014, Article ID: 304120. https://doi.org/10.1155/2014/304120

[37] Veeramachaneni, K., Vladislavleva, E. and O’Reilly, U.M. (2012) Knowledge Mining Sensory Evaluation Data: Genetic Programming, Statistical Techniques, and Swarm Optimization. Genetic Programming and Evolvable Machines, 13, 103-133. https://doi.org/10.1007/s10710-011-9153-2

[38] Van Ruth, S., Brouwer, E., Koot, A. and Wijtten, M. (2014) Seafood and Water Management. Foods, 3, 622-631. https://doi.org/10.3390/foods3040622

[39] Sultana, S., Parween, S. and Hossain, M.A. (2011) Biochemical Analysis of Some Dried SIS Fishes of the River Padma in Rajshahi. Journal of Life and Earth Science, 6, 39-43. https://doi.org/10.3329/jles.v6i0.9719

[40] Abbasi, A., Babaali, E. and Berizi, E. (2019) Effect of Radiation, Heating, High Pressure, and the Commercial Processing Method on Reduction and/or Elimination of Patulin in Fruit and Vegetable Products: A Systematic Review. Toxin Reviews. https://doi.org/10.1080/15569543.2019.1584823

[41] Abdel-Haleem, A.M. and Omran, A.A. (2014) Preparation of Dried Vegetarian Soup Supplemented with Some Legumes. Food and Nutrition Sciences, 5, 2274. https://doi.org/10.4236/fns.2014.522241

[42] Flowra, F.A., Tumpa, A.S. and Islam, M.T. (2012) Biochemical Analysis of Five Dried Fish Species of Bangladesh. University Journal of Zoology, Rajshahi University, 31, 9-11. https://doi.org/10.3329/ujzru.v31i0.15373

[43] Abbey, L., Glover-Amengor, M., Atikpo, M.O., Atter, A. and Toppe, J. (2017) Nutrient Content of Fish Powder from Low Value Fish and Fish Byproducts. Food Science \& Nutrition, 5, 374-379. https://doi.org/10.1002/fsn3.402

[44] Majumdar, B.C. (2018) Comparison of the Changes in Nutritional Quality of Three Important Small Indigenous Fish Species in Bangladesh at Room Temperature $\left(27^{\circ}-31^{\circ} \mathrm{C}\right)$ : A Review. Journal of Animal Research and Nutrition, 2, 15. https://doi.org/10.21767/2572-5459.100035 
[45] Islam, M.T., Ahmed, S., Sultana, M.A., Tumpa, A.S. and Flowra, F.A. (2013) Nutritional and Food Quality Assessment of Dried Fishes in Singra Upazila under Natore District of Bangladesh. Trends in Fisheries Research, 2, 2319-4758.

[46] Islam, M., Mahmud, N., Nawas, T., Fang, Y. and Xia, W. (2018) Health Benefits and Spray Drying Microencapsulation Process of Fish Oil Health Benefits and Spray Drying Microencapsulation Process of Fish Oil (Omega-3). American Journal of Food Science and Nutrition Research, 5, 29-42.

[47] Trautvetter, U., Ditscheid, B., Jahreis, G. and Glei, M. (2018) Calcium and Phosphate Metabolism, Blood Lipids and Intestinal Sterols in Human Intervention Studies Using Different Sources of Phosphate as Supplements-Pooled Results and Literature Search. Nutrients, 10, 936. https://doi.org/10.3390/nu10070936

[48] Hei, A. and Sarojnalini, C. (2012) Proximate Composition, Macro and Micro Mineral Elements of Some Smoke-Dried Hill Stream Fishes from Manipur, India. Nature and Science, 10, 59-65.

[49] Medeiros, R.J., dos Santos, L.M.G., Freire, A.S., Santelli, R.E., Braga, A.M.C., Krauss, T.M. and Jacob, S.D.C. (2012) Determination of Inorganic Trace Elements in Edible Marine Fish from Rio de Janeiro State, Brazil. Food Control, 23, 535-541. https://doi.org/10.1016/j.foodcont.2011.08.027

[50] Reyahi-Khoram, M., Setayesh-Shiri, F. and Cheraghi, M. (2016) Study of the Heavy Metals $(\mathrm{Cd}$ and $\mathrm{Pb}$ ) Content in the Tissues of Rainbow Trouts from Hamedan Coldwater Fish Farms. Iranian Journal of Fisheries Sciences, 15, 858-869.

[51] Ahmad, A. and Shuhaimi-Othman, M. (2010) Heavy Metal Concentrations in Sediments and Fishes from Lake Chini, Paliang, Malaysia. Journal of Biological Sciences, 10, 93-100. https://doi.org/10.3923/jbs.2010.93.100

[52] Kumar, P.S., Ramakrishnan, K., Kirupha, S.D. and Sivanesan, S. (2010) Thermodynamic and Kinetic Studies of Cadmium Adsorption from Aqueous Solution onto Rice Husk. Brazilian Journal of Chemical Engineering, 27, 347-355. https://doi.org/10.1590/S0104-66322010000200013

[53] Malum, Y.M. and Salihu, L. (2017) Determination of Heavy Metals in Hibiscus cannabinus and Moringa oleifera Cultivated at Zango Abattoir, Tudun Wada, Kaduna Metropolis. International Journal of Sustainable Development Research, 3, 32. https://doi.org/10.11648/j.ijsdr.20170304.11

[54] Flowra, F.A., Bayezid, M.A., Alam, M.M., Hussain, M.A. and Jahan, S.N. (2017) Safety Aspects: An Assessment of Heavy Metals in Dried Fishes of Chalan Beel. Journal of Agricultural Engineering and Food Technology, 4, 82-86.

[55] In't Veld, J.H.H. (1996) Microbial and Biochemical Spoilage of Foods: An Overview. International Journal of Food Microbiology, 33, 1-18. https://doi.org/10.1016/0168-1605(96)01139-7

[56] Food Standards Australia. New Zealand. (2018) Compendium of Microbiological Criteria for Food.

[57] Pradhan, N., Shrestha, M.K., Rai, S., Jha, D.K. and Sah, S.K. (2018) Quality Assessment of Dried Mrigal (Cirrhunus mrigala) Chhari Fish from Different Market Outlets of Nepal. International Journal of Fisheries and Aquatic Studies, 6, 463-471.

[58] Al-Reza, S., Karmaker, S., Hasan, M., Roy, S., Hoque, R. and Rahman, N. (2015) Effect of Traditional Fish Processing Methods on the Proximate and Microbiological Characteristics of Laubuka dadiburjori during Storage at Room Temperature. Journal of Fisheries and Aquatic Science, 10, 232.

https://doi.org/10.3923/jfas.2015.232.243 
[59] Immaculate, K., Giftson, H., Saritha, K. and Patterson, J. (2015) Studies on the Nutritional and Microbiological Quality of Smoked Tuna Fish (Auxis thazard) in Tuticorin, South East Coast of India. International Journal of Food Quality and Safety, 1, 28-38.

[60] Socaciu, M.I., Semeniuc, C. and Vodnar, D. (2018) Edible Films and Coatings for Fresh Fish Packaging: Focus on Quality Changes and Shelf-Life Extension. Coatings, 8, 366. https://doi.org/10.3390/coatings8100366

[61] Banda, J., Chigwechokha, P., Singini, W., Kamanula, J., Msiska, O. and Simbeye, J. (2017) The Shelf Life of Solar Tent Dried and Open Sun Dried Diplotaxodon limnothrissa (Ndunduma)-Pisces; Cichlidae. International Journal of Fisheries and Aquatic Studies, 5, 212-218.

[62] Farid, F.B., Latifa, G.A., Nahid, M.N. and Begum, M. (2014) Effect of Sun-Drying on Proximate Composition and $\mathrm{pH}$ of Shoal Fish (C. striatus, Bloch, 1801) Treated with Salt and Saltturmeric Storage at Room Temperature $\left(27^{\circ} \mathrm{C}-30^{\circ} \mathrm{C}\right)$. IOSR Journal of Agriculture and Veterinary Science, 7, 1-8. https://doi.org/10.9790/2380-07930108

[63] Odour-Odote, P., Shamasundar, B.A., Booman, A.C., Howell, N.K., Parin, M.A. and Zugarramurdi, A. (2016) Effect of Raw Material Quality on Quality and Yield of Dried Fish Products. International Journal, 3, 55. https://doi.org/10.15379/2408-9826.2016.03.02.04

[64] Özyurt, G., Kuley, E., Özkütük, S. and Özogul, F. (2009) Sensory, Microbiological and Chemical Assessment of the Freshness of Red Mullet (Mullus barbatus) and Goldband Goatfish (Upeneus moluccensis) during Storage in Ice. Food Chemistry, 114, 505-510. https://doi.org/10.1016/j.foodchem.2008.09.078

[65] Cai, Q., Wu, Y., Li, L., Wang, Y., Yang, X. and Zhao, Y. (2017) Lipid Oxidation and Fatty Acid Composition in Salt-Dried Yellow Croaker (Pseudosciaena polyactis) during Processing. Journal of Ocean University of China, 16, 855-862. https://doi.org/10.1007/s11802-017-3233-8

[66] Siriskar, D.A., Khedkar, G.D. and Lior, D. (2013) Production of Salted and Pressed Anchovies (Stolephorus sp.) and Its Quality Evaluation during Storage. Journal of Food Science and Technology, 50, 1172-1178. https://doi.org/10.1007/s13197-011-0450-9

[67] Nurullah, M., Kamal, M., Islam, M.N., Ahasan, C.T. and Thilsted, S.H. (2007) Shelf Life of Dried Products from Small Indigenous Fish Species under Various Packing and Storage Conditions. Bangladesh Journal of Fisheries Research, 11, 229-236.

[68] Tenyang, N., Tiencheu, B. and Womeni, H.M. (2018) Effect of Smoking and Refrigeration on Lipid Oxidation of Clupea harengus. A Fish Commonly Consumed in Cameroon. Food Science \& Nutrition, 6, 464-473. https://doi.org/10.1002/fsn3.575

[69] Moneim, A., Sulieman, E. and Mustafa, W.A. (2012) Quality Characteristics of Dried Fish Obtained from Eldeim Area, Central Sudan. International Journal of Food Science and Nutrition Engineering, 2, 1-6. https://doi.org/10.5923/j.food.20120201.01

[70] Özogul, Y., Özyurt, G., Özogul, F., Kuley, E. and Polat, A. (2005) Freshness Assessment of European Eel (Anguilla anguilla) by Sensory, Chemical and Microbiological Methods. Food Chemistry, 92, 745-751. https://doi.org/10.1016/j.foodchem.2004.08.035 